\title{
Characteristics of Fermentation Drink made from Juice of Winged Bean Sprouts (Psophocarpus tetragonolobus) and Red Sweet Potato (Ipomoea batatas)
}

\author{
Novelina ${ }^{\#}$, Kesuma Sayuti, and Fitri Nur Rahmadani \\ Department Agricultural Processing Technology, Agricultural Technology Faculty, Andalas University, West Sumatra, Indonesia \\ E-mail: "\#ovelinasutanto@yahoo.com
}

\begin{abstract}
Fermented milk is a product that was produced from fermentation of fresh milk using lactic acid bacteria, such as Lactobacillus bulgaricus and Streptococcus thermophilus. A variety of plant materials can also be used as raw material in making of fermentation drinks, such as nuts and tubers. The purpose of this study was to investigate the characteristics of fermentation drink made from juice of winged bean sprout and red sweet potatoes. The treatment in this study is the level of mixing between juice of winged bean sprout with red sweet potatoes, consist of ;A (30:70), B (40:60), C (50:50), D (60:40) and E (70:30). Completely randomized design had been used with 5 treatments and 3 replications. The data colected was pH, viscosity, protein content, fat content, total solids, total acid, ash content, calcium content, total lactic acid bacteria, total plate count and sensory evaluation. Data processing is performed using statistical 8, followed by Tuckey test HSD All-Pair wise Comparisons Test at level of 5\%. Mixing of winged bean sprouts with red sweet potato can increase the value of $\mathrm{pH}$, viscosity, protein content, fat content, total solids, total acid, ash content, calcium content, and total lactic acid bacteria. The best product was the product of $B(40 \%$ winged bean sprout and $60 \%$ red sweet potatoes) already meets SNI $7552: 2009$, contain : $2.36 \%$ protein content, fat content of $1.24 \%$, $18.77 \%$ total solids, pH was $4,2,0.54 \%$ total acid, $0.23 \%$ ash content, $0.173 \%$ calcium content, viscosity was $3.56 \mathrm{DPA}$, total lactic acid bacteria (CFU / ml) was $1.9 \times 10^{10}$, total plate count was $2.1 \times 10^{10}(\mathrm{CFU} / \mathrm{ml})$.
\end{abstract}

Keywords - weang bean sprout; red sweet potato; fermented drink

\section{INTRODUCTION}

Winged bean (Psophocarpus tetragonolobus L.) is a plant that is rich in protein and carbohydrates. Reference (1) shows all parts of the winged bean plant can be used. Leaves, flowers, and fruit of youth can be used as a vegetable and the tubers are edible.

The seeds of winged bean ripe has not optimally used, as in (2) shows that dry winged seeds ripe are the most nutritious part of the plant, because of the high protein content $(30 \%-42 \%)$ and have good amino acid composition. Winged bean seeds are very rich in the amino acid lysine, but limited to the amino acid cysteine and methionin.

Methionin and cysteine deficiency in winged bean seeds can be covered by combining it with other foods rich in methionin and cysteine. Tubers is one food that is rich in the amino acids methionin and cysteine.

Winged bean seeds not optimally used, it has an unpleasant flavor that is not favored (off flavor), as in (2) the smell of rotten on winged bean seeds caused by the activity of lipoxygenase enzymes that are naturally present in the beans. Reference (1) shows that germination is one way to eliminate the smell of rotten beans.

Red sweet potatoes are rich in carbohydrates and carotene. One part of the carbohydrates are oligosaccharides, that are a good medium for growing lactic acid bacteria, so the sweet potato can also be used as raw material of fermentation drinks. Refference (3) shows in red sweet potatoes contain $1208 \mathrm{ug} / 100 \mathrm{~g}$ total carotene. It cause the color of the drink become reddish color.

Fermented drink is defined as a result of the fermentation of fresh milk that has been pasteurized by using specific microbial cultures. Fermented milk known as yogurt, has a distinctive sour taste due to bacterial activity of Lactobacillus bulgaricus and Streptococcus thermophillus (4). Yogurt can also be made from the other raw material, like juice of tubers and nuts. The purpose of this study was to analyse the effect of mixing of winged bean sprouts juice and red sweet potatoes juice on the characteristic of fermented drink. 


\section{METHODOLOGY}

The design used in this study was a completely random design (CRD) with 5 treatments and 3 replications. Data processing was done using statistically 8 , if the data was significantly different continued by the Tukey HSD test at alfa $=5 \%$. The Treatment is a comparison of winged bean sprout juice with red sweet potatoes juice.

\section{A. Research procedures is}

1) Making of winged bean sprouts (as in 7, the modified)

Winged bean cleaned of impurities such as sand and stone, and then washed by water. Soak the winged bean in water (1:5) for 36 hours then drain and spread it in a hollow basin that has been coated with a wet cloth to keep the seeds moist. Avoid sunlight for germination and cover bowl with a damp cloth surface. Reference (1), winged bean seed germination for 72 hours can decrease the activity of lipoxygenase that cause unpleasant odors.

2) Making of winged bean sprouts juice (as in 7, the modified)

Wash the sprouts from inherent impurities and the epidermis. Boiled at a temperature of $80-90^{\circ} \mathrm{C}$ for $3 \mathrm{~min}$. Then sprouts be drained and then blended until pureed. The amount of water added to the dry winged bean sprout was six times, then filtered and squeezed with filter cloth. Filtered fluid is called the winged bean sprouts raw Juice.

\section{3) Making of Red Sweet Potato juice (as in 9, the} modified).

Red sweet potatoes peeled and washed and cut into pieces, washed and put into blender. Added with water as much as twice of sweet potatoes weight and then was blended. Heat the red sweet potato puree at $700 \mathrm{C}$ for 30 minutes. Put in the room until the temperature of red sweet potato porridge was $450 \mathrm{C}$ and then filtered the filtrate.

\section{4) Making of Starter (as in 9, the modified)}

Winged bean sprouts juice and red sweet potatoes juice (50: 50) added with raw skim milk (w/v) $12 \%$, sucrose (w / v) $5 \%$, xanthan gum $(\mathrm{w} / \mathrm{v}) 0.1 \%$, then pasteurized at $80^{\circ}$ $\mathrm{C}$ for 15 minutes. Then entered into a glass bottle and then cooled at $37^{\circ} \mathrm{C}$. then inoculated with pure cultures of Lactobacillus bulgaricus and Streptococcus thermophillus as much as $2 \%$, and fermented at $37^{\circ} \mathrm{C}$ for 24 hours.

5) Making of Fermentation drink made from juice of winged bean sprouts and red sweet potatoes (as in 8 , the modified).

Winged bean sprouts juice and juice of red sweet potatoes prepared in according to the treatment., and then was added with skim milk (w/v) $12 \%, 5 \%$ sucrose $(\mathrm{w} / \mathrm{v})$, xanthan gum $(\mathrm{w} / \mathrm{v}) \quad 0.1 \%$ then heated at $800 \mathrm{C}$ for 15 minutes and then cooled to $37 \mathrm{C}$, and Inoculated with $2 \%(\mathrm{w} / \mathrm{v})$ starter of Lactobacillus and Streptococcus thermopillus bacillus then fermented at $370 \mathrm{C}$ for 24 hours.

\section{B. Observation}

For starter, consist of total lactic acid bacteria and $\mathrm{pH}$. For fermentation drink made from winged bean sprouts with red sweet potato juice consisit of the level of protein, fat, total solids, $\mathrm{pH}$, total acid, ash, calcium levels, viscosity, total plate count, total lactic acid bacteria, all analyzes refer to (5) and the analyze of organoleptic test including the color, flavor, taste, consistency and appearance refer to (6).

\section{RESULT AND DISCUSSION}

\section{A. Starter}

The observasion of Lactobacillus bulgaricus and Streptococcus thermophilus consist of $\mathrm{pH}$ and lactic acid bacteria as shown in Table 1. The starter had been inoculated in the fermentation medium is estimated as $106 \mathrm{CFU} / \mathrm{ml}$ of lactic acid bacteria (before fermentation). Reference (5) shows the amount of lactic acid bacteria in the starter at least $1 \mathrm{x} 106 \mathrm{CFU} / \mathrm{ml}$. After fermentation is predicted, there is a increasing in the number of lactic acid bacteria.

TABEL 1

THE OBSERVASION OF STARTER

\begin{tabular}{|l|l|l|}
\hline No & Observasion & Value \\
\hline 1 & $\mathrm{pH}$ starter L. Bulgaricus & 3.38 \\
\hline 2 & $\mathrm{pH}$ starter S. Thermophillus & 3.63 \\
\hline 3 & $\begin{array}{l}\text { Total Lactic acic bacteria starter } \\
\text { L.bulgaricus }\end{array}$ & $8.9 \times 10^{8} \mathrm{CFU} / \mathrm{ml}$ \\
\hline 4 & $\begin{array}{l}\text { Total Lactic acic bacteria starter } \\
\text { L.bulgaricus }\end{array}$ & $3.8 \times 10^{8} \mathrm{CFU} / \mathrm{ml}$ \\
\hline
\end{tabular}

\section{B. Fermented Drink}

Observation of the fermented drink made from a mixture of winged bean sprout juice with sweet potato red juice, consisit of the level of protein, fat, total solids, $\mathrm{pH}$, total acid, ash content, calcium content, viscosity, total plate count, and total lactic acid bacteria and sensory evaluation including the color, the taste, flavor, consistency and appearance. The content of amino acid was analyzed in the best product using sensory evaluation.

TABEL 2

Chemical, Physical AND Microbiological Analysis OF

FERMENTED DRINK

\begin{tabular}{|c|c|c|c|c|c|}
\hline \multirow[b]{2}{*}{ Parameter } & \multicolumn{5}{|c|}{ Value } \\
\hline & $\begin{array}{l}\mathbf{A} \\
(\mathbf{3 0} \% \\
: \mathbf{7 0} \%)\end{array}$ & $\begin{array}{l}\text { B(40\% } \\
: 60 \%)\end{array}$ & $\begin{array}{l}\mathrm{C}(50 \% \\
: 50 \%)\end{array}$ & $\begin{array}{l}\mathrm{D}(60 \% \\
: 40 \%)\end{array}$ & $\begin{array}{l}\mathrm{E}(70 \% \\
: 30 \%)\end{array}$ \\
\hline Protein $(\%)$ & $1,74 \mathrm{a}$ & $2,36 \mathrm{ab}$ & $3,06 \mathrm{bc}$ & $3,85 \mathrm{~cd}$ & $4,46 \mathrm{~d}$ \\
\hline Fat (\%) & $0,75 \mathrm{a}$ & $1,24 \quad b$ & $1,61 \mathrm{c}$ & $2,13 \mathrm{~d}$ & $2,63 \mathrm{e}$ \\
\hline Ash (\%) & $0,20 \mathrm{a}$ & $0,23 \mathrm{ab}$ & $0,25 \mathrm{ab}$ & $0,30 \quad a b$ & $0,33 \mathrm{~b}$ \\
\hline Calcium $(\%)$ & 0,12 & 0,17 & 0,56 & 0,83 & 1,08 \\
\hline $\mathrm{pH}$ & $4,25 \mathrm{a}$ & $4,20 \mathrm{ab}$ & $4,14 \quad b$ & $4,03 \mathrm{c}$ & $3,94 \mathrm{~d}$ \\
\hline Total acid (\%) & $\begin{array}{l}17,89 \\
\mathrm{a}\end{array}$ & $18,77 \mathrm{~b}$ & $19,11 \mathrm{c}$ & $19,63 \mathrm{~d}$ & $19,92 \mathrm{e}$ \\
\hline $\begin{array}{l}\text { Total solids } \\
(\%)\end{array}$ & $0,51 \mathrm{a}$ & $0,54 \mathrm{a}$ & $0,59 \quad b$ & 0,62 bc & $0,65 \mathrm{c}$ \\
\hline Viscosity (dpa) & 3,03 a & $3,56 \mathrm{~b}$ & $4,50 \mathrm{c}$ & $5,23 \mathrm{~d}$ & $\begin{array}{l}5,63 \\
d\end{array}$ \\
\hline $\begin{array}{l}\text { Total BAL } \\
(\mathrm{CFU} / \mathrm{ml})\end{array}$ & $\begin{array}{l}1,5 \mathrm{x} \\
10^{10}\end{array}$ & $1,9 \times 10^{10}$ & $2,4 \times 10^{10}$ & $2,7 \times 10^{10}$ & $\begin{array}{l}2,8 \times \\
10^{10}\end{array}$ \\
\hline $\begin{array}{l}\text { Total Plate } \\
\text { count }(\mathrm{CFU} / \mathrm{ml})\end{array}$ & $\begin{array}{l}1,7 \times \\
10^{10}\end{array}$ & $\begin{array}{l}2,1 \mathrm{x} \\
10^{10}\end{array}$ & $\begin{array}{l}2,6 \mathrm{x} \\
10^{10}\end{array}$ & $\begin{array}{l}2,8 \mathrm{x} \\
10^{10}\end{array}$ & $\begin{array}{l}2,9 x \\
10^{10}\end{array}$ \\
\hline
\end{tabular}

The numbers in the same row followed by the same small letters, no significant differently according to Tukey's test at $\mathbf{5 \%}$ significance level.

Table 2, shows that the winged bean sprouts juice mixed with juice of red sweet potatoes have a significant effect on 
the levels of protein, fat, ash content, $\mathrm{pH}$, total acid, total solids and viscosity of fermented drinks produced. The higher the winged bean sprout juice is added, the higher protein content, fat content, ash content, calcium content, total acid, total solids, and the viscosity, but the lower of the $\mathrm{pH}$ value.

\section{1) Protein}

The main source of protein in the fermented drink derived from winged bean sprouts juice, protein content of winged seeds that mature between $32-41 \%$ (1). There are different type of amino acids in protein contained in the fermentation drink, where cultures Lactobacillus bulgaricus and Streptococcus thermophilus were inoculated will use amino acids to live and proliferate (multiplying).

\section{2) Fat}

The main sources of fat in the fermented drink derived from winged bean seeds. Reference (2), besides a high protein, Winged bean seed was also has relatively high fat that is about $15-20 \%$. So, the higher the level of sprouts winged bean juice was added, the higher the level of fat in fermented drink.

\section{3) Total Solids}

The ripe winged bean seeds are high in protein and other components that are part of the high total solids. Reference (4) show that decreasing of $\mathrm{pH}$ causes the milk proteins coagulate into a solid or condensed period.

\section{3) $p H$}

Increased acidity of the fermented drink is caused there is a change of lactose into lactic acid by lactic acid bacteria inoculated; lactic acid can lower the $\mathrm{pH}$ so that it will coagulate milk protein (4). Clumps of protein formed will be used by the lactic acid bacteria as a source of nutrition for the activity and breeding. A high number of bacteria cells have a high ability to metabolize sugar anyway fermentation of media to get energy and produce acid. The more acidic $\mathrm{pH}$ produced it will go down.

\section{4) Total Acid}

Total acids expressed as lactic acid. Related to the total acid $\mathrm{pH}$ value, the higher the value of lactic acid, the lower the $\mathrm{pH}$ value. Reference (4) show that lactic acid resulting from the metabolism of carbohydrates will lower the $\mathrm{pH}$ value the environment.

\section{5) Ash Content}

Ash content is closely related with the minerals contained in the material. Ash content in the fermented drink is influenced by substrate red winged bean, sweet potatoes, and skim milk. Reference (2)shows, winged bean contain 3.3 to $4.3 \%$ ash which consists of several types of minerals such as calcium, magnesium, phosphorus and iron. Furthermore Hidayat et al., (2006) mentioned that yams contain $0.39 \%$ ash consist of calcium, iron, magnesium, zinc, and potassium. The higher level of comparison winged bean sprout juice added, the higher ash content of the fermented drink.

\section{6) Calcium levels}

Winged bean and sweet potatoes contain calcium. The level of calcium is related with ash content. The higher the ash content, the calcium levels are also high. Table 8 shows that the higher the ratio of winged bean sprout juice is added, the higher calcium level. Function of calcium (lime) for the body is for the formation of bones, teeth formation, growth, blood clotting and muscle contraction (12)

\section{7) Viscosity}

Viscosity has a proportional relationship to the total solids; the higher winged bean sprouts added, the higher the viscosity of fermented drinks. The texture of the fermented drink is thick that was occurs because of denaturation of the protein of raw materials. It is one of the major components of the total solids. Reference (10) shows denaturation of the protein clots that cause fermentation product becomes thick.

\section{8) Total Lactic Acid Bacteria}

In the making of fermented drinks, total solids have a very important role, that is as a source of nutrition for the activity and proliferation of bacteria, the higher total lactic acid, the higher the total solids in fermented drinks, besides the total solids is also important to establish the texture and flavor components of the fermentation products (11).

Increasing of cell number during fermentation is due to the growth of lactic acid bacteria. Adequate availability of nutrients in the substrate will be utilized by BAL to grow and thrive, as in (11) shown that availability of the nutrients is needed to increase the number of bacteria high bacterial cells.

\section{9) Total Plate Count}

Total plate count in each treatment equal to the total lactic acid bacteria that is are both powers of 10, it means the products produced there are no contaminants. Reference (4) mention the use of LAB fermented milk can prevent cell multiplication of pathogenic bacteria, these lactic acid bacteria can against pathogenic microbes, that is pathogenic bacteria can not grow or grow very slowly at $\mathrm{pH} 4.6$.

10) Organoleptic Test

Organoleptic test of the fermented drink made from a mixture of winged bean sprout juice with the juice of red sweet potatoes is shown in Figure 1.

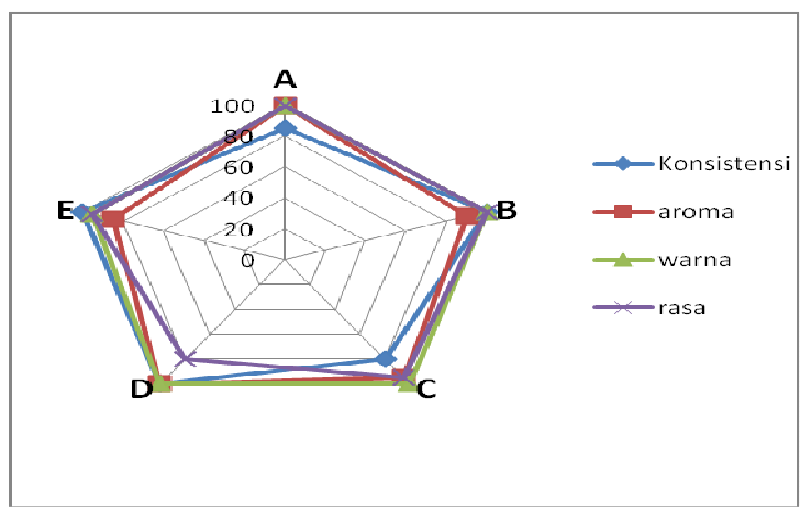

Fig 1. Radar Graph of the percentage of panelists who expressed disliked of the products 


\section{Appearance}

In general appearance fermented drinks is acceptable $100 \%$ by the panelists. If viewed from favorite of the panelists, treatment B has a preference level of $90 \%$ (liked $60 \%$ level, and really liked $30 \%$ ). So it can be concluded that treatment $\mathrm{B}$ is a fermented drink with the percentage of revenue and the highest percentage compared to treatment A.

The tekstur was lumpy, it is due to protein clotting from raw materials and proteins from skim milk. Reference (4) shows, during the fermentation, bacteria will break down lactose (milk sugar) into lactic acid. This will increase the acidity of the environment that causes the milk proteins to be solid or viscous.

\section{Consistency}

Consistency of fermentation drinks made from a mixture of winged bean sprout juice with red sweet potato juice can be accepted by panelists with percentages ranging from 80$100 \%$. Highest percentage of acceptance toward consistency found in treatments $\mathrm{B}, \mathrm{D}, \mathrm{E}$ that is respectively $100 \%$. Consistency of fermented drinks can be also caused by coagulation proteins at low $\mathrm{pH}$.

\section{Flavor}

Fifty percent of the panelists liked A product (liked 45\% and really liked 5\%). Getting higher the number of winged bean sprout juice is added, getting less flavored the product, it is associated with a slightly sour smell and unpleasant odor of cooked winged bean

\section{Color}

Eighty four percent of the panelists liked A and B product (liked $75 \%$ and really liked $10 \%$ ). Increasing number of winged bean sprout juice is added, getting less flavored the product, it is associated with a slightly sour smell and unpleasant odor of cooked winged bean

The color of the fermented drink is orange to pale yellow. The higher of the level of red sweet potato, the color become orange. Red sweet potato has a distinctive taste and rich in carotenoid pigments that can be natural dyes.

\section{Taste}

Fifty percent of the panelist liked B product (liked 45\% and really liked $10 \%$ ). Taste of the drinks made from a mixture of winged bean sprouts with red sweet potato has a sweet and sour taste. Sweet taste in fermented drinks is not only produced from sucrose were added, but it also comes from the juice of red sweet potatoes. Reference (4) shows distinctive sour taste is caused by bacteria Lactobacillus bulgaricus and Streptococcus thermophilus that breaks down lactose into lactic acid.

\section{Amino acid}

Based on all of the testing that has been done shows that $\mathrm{B}$ product is the best product (winged bean sprouts juice $40 \%$ : red sweet potato juice $60 \%$ ). The most preferred product using sensory evaluation and has fulfilled the requirements as fermented drinks. Amino acid analysis performed on B product using HPLC as shown in the table 3 .
TABLE 3.

Protein Content AND AMINo ACID In FERMENTEd DRINK

\begin{tabular}{|l|l|l|l|}
\hline Parameter & Value & Parameter & Value \\
\hline Protein & 21.7 & Alanine & 0.4 \\
\hline Aspartic acid & 1.1 & Tyrosine & n.d \\
\hline Glutamic acid & 2.0 & Methionine & 0.2 \\
\hline Serine & 0,5 & Valine & 0.5 \\
\hline Histidine & 0,2 & Phenylalanine & 0.6 \\
\hline Glycine & 1.8 & Heucine & 0.5 \\
\hline Threonine & 1.3 & Leucine & 0.9 \\
\hline Arginine & 0.4 & Lysine & 0.7 \\
\hline
\end{tabular}

\section{CONCLUSIONS}

Mixing of winged bean sprouts juice with red sweet potato juice can increase the value of $\mathrm{pH}$, viscosity (DPA), protein content $(\%)$, fat content $(\%)$, total solids $(\%)$, total acid $(\%)$, ash content $(\%)$, calcium levels $(\%)$, total lactic acid bacteria (CFU / ml), and total plate count (CFU / ml). B product (winged bean sprouts juice 40\%: red sweet potato juice $60 \%$ ) meets the requirements as in (5) that are protein content of $2.36 \%, 1.24 \%$ fat, $18.77 \%$ total solids, $\mathrm{pH} 4,2$, total acid $0.54 \%, 0.23 \%$ ash, $0.17 \%$ calcium, $3.56 \mathrm{dPa} . \mathrm{S}$ viscosity, total $1.9 \times 1010$ lactic acid bacteria (CFU / ml), total plate count $2,1 \times 1010(\mathrm{CFU} / \mathrm{ml})$ and B product was the best product.

\section{REFERENCES}

[1] Kanetro, B. dan Hastuti, S. Ragam Produk Olahan KacangKacangan. Universitas Wangsa Mangala. Yogyakarta.2006.

[2] Astawan, M. Sehat dengan Hidangan Kacang-Kacangan dan BijiBijian. Penebar Swadaya. Jakarta. 2009.

[3] Mahmud, M. K. Dan Zulfianto, N. A. Tabel Komposisi Pangan Indonesia. Elex Media Komputindo. 2009.

[4] Winarno, F.G. dan Fernadez, I.E. Susu dan Produk Fermentasinya M-Brio Press. Bogor. 2007.

[5] Standar Nasional Indonesi (SNI). Susu Fermentasi. Badan Standardisasi Nasional (BSN). 2009.

[6] Soekarto S.T. Penilaian organoleptik untuk industri pangan dan hasil pertanian. Pusbangtepa/food technology development center. IPB.1981.

[7] Hariyuni, A. Studi Pembuatan Susu Kecambah Kacang Hijau ( Vigna radiata L Wilezet ). skripsi. Fakultas Pertanian Unand. Padang. 2006.

[8] Hidayat, N., Nurika, I. dan Dania, W.A.P. Membuat Minuman Prebiotik dan Probiotik. Trubus Agrisarana. Surabaya. 2006.

[9] Karleni, V. Pembuatan Minuman Fermentasi Sari Kacang Merah ( Phaseolus vulgaris L.) dengan Menggunakan Starter Dadih. skripsi. Fateta Unand.Padang. 2010.

[10] Fratiwi, Yulneriwarni dan Noverita. Fermentasi Kefir dari Susu Kacang-Kacangan. Fakultas Biologi Universitas Nasional. Jakarta. 2008 .

[11] Chairunisa, H. Penambahan susu bubuk fullcream pada pembuatan produk minuman fermentasi dari bahan baku ekstrak jagung manis skripsi. Fakultas Perternakan Universitas padjajaran. Bandung. 2009.

[12] World Organization Geneva. Trace Elements in Human Nutrition and Health. 1996 